\title{
Coral community responses to declining water quality: Whitsunday Islands, Great Barrier Reef, Australia
}

\author{
Angus Thompson - Thomas Schroeder • \\ Vittorio E. Brando $\cdot$ Britta Schaffelke
}

Received: 14 September 2013/ Accepted: 22 August 2014/Published online: 2 September 2014

(C) The Author(s) 2014. This article is published with open access at Springerlink.com

\begin{abstract}
A five-year period (2002-2006) of belowmedian rainfall followed by a six-year period (2007-2012) of above-median rainfall and seasonal flooding allowed a natural experiment into the effects of runoff on the water quality and subsequent coral community responses in the Whitsunday Islands, Great Barrier Reef (Australia). Satellite-derived water quality estimates of total suspended solids (TSS) and chlorophyll- $a$ (Chl) concentration showed marked seasonal variability that was exaggerated during years with high river discharge. During above-median rainfall years, Chl was aseasonally high for a period of 3 months during the wet season (February-April), while TSS was elevated for four months, extending into the dry season (March-June). Coinciding with these extremes in water quality was a reduction in the abundance and shift in the community composition, of juvenile corals. The incidence of coral disease was at a maximum during the transition from years of below-median to years of abovemedian river discharge. In contrast to juvenile corals, the cover of larger corals remained stable, although the composition of communities varied along environmental gradients. In combination, these results suggest opportunistic
\end{abstract}

Communicated by Ecology Editor Dr. Stuart Sandin

\footnotetext{
A. Thompson $(\bowtie) \cdot$ B. Schaffelke

Australian Institute of Marine Science, Townsville, QLD 4810, Australia

e-mail: a.thompson@aims.gov.au

T. Schroeder

Commonwealth Scientific and Industrial Research Organisation, Land and Water, Brisbane, QLD 4001, Australia

V. E. Brando

Commonwealth Scientific and Industrial Research Organisation, Land and Water, Canberra, ACT 2601, Australia
}

recruitment of corals during periods of relatively low environmental stress with selection for more tolerant species occurring during periods of environmental extremes.

Keywords Coral community $\cdot$ River runoff $\cdot$ Coral juveniles $\cdot$ Coral disease $\cdot$ Satellite remote sensing

\section{Introduction}

It has long been recognised that key environmental parameters controlling the local distribution of coral species include their exposure to sediment (e.g., Darwin 1851) and the availability of light (Dana 1853). Following these early observations has been a large body of literature serving to further identify physical and chemical environmental conditions that are stressful to corals (see reviews by Fabricius 2005, 2011; Erftemeijer et al. 2012). The repeated conclusion has been that eutrophication, a term taken here to encompass nutrient enrichment, increased sedimentation and the introduction of toxins related to human activities, similar to Tomascik and Sanders (1987) in reference to coral reefs, has resulted in coral community degradation (Fabricius 2005).

The term eutrophication remains particularly pertinent to corals as it explicitly acknowledges that stress to colonies is a result of the interactions between many environmental parameters. For example, if one considers the increased supply of sediments, local hydrodynamics will determine the balance between the accumulation or resuspension and removal of settling material (Storlazzi et al. 2004). The depth of the water will influence the exposure to wave-driven resuspension (Wolanski et al. 2005), but also light attenuation as a result of turbidity. Grainsize will influence the effectiveness of corals' self- 
cleaning mechanisms (Stafford-Smith 1993). In combination, the availability of nutrients will enhance microbial activity both within the water column and sediment, altering the composition of settling material (Bainbridge et al. 2012), further influencing the energetic cost of selfcleaning, limiting survival of coral recruits (Fabricius et al. 2003) and promoting coral disease (Weber et al. 2006, 2012).

Physiological differences between species govern the ability to maintain a positive energy balance along environmental gradients (Anthony and Connolly 2004), e.g., the efficiency of sediment shedding (Rogers 1983; StaffordSmith 1993) and the ability to utilise a range of energy sources (Anthony and Fabricius 2000). Such physiological differences likely explain observed changes in species composition of coral communities along environmental gradients such as light availability, exposure to sedimentation and water movement (Loya 1976; Rogers 1979; Sheppard 1982; Kleypas et al. 1999). Within species, this 'niche' may be broad as physiological (Falkowski et al. 1990; Anthony and Fabricius 2000; Hennige et al. 2008) and morphological (Todd 2008) plasticity allows individual corals to acclimate to local environmental conditions. As a result, coral communities within a particular location will be both adapted but also acclimated to those conditions, meaning that species-specific tolerances will vary as a function of a coral's environmental setting (as discussed by Erftemeijer et al. 2012). The susceptibility to eutrophication also varies among life-history stages with egg production, fertilisation, settlement and postsettlement survival all sensitive to substantially lower levels of sediment and/or nutrient exposure than adult colonies (Fabricius 2005, 2011).

Degradation of coral reef communities in response to acute increases in sediment supply, such as those caused by dredging, is well documented (Erftemeijer et al. 2012), as are those resulting from severe eutrophication in association with local nutrient discharges (e.g., Walker and Ormond 1982; Pastorok and Bilyard 1985; Loya 2004). Responses of coral communities attributed to chronic degradation of environmental conditions have largely been inferred from observed differences in community attributes such as species composition, coral cover, colony size distributions, incidence of disease, or abundance of space competitors along environmental gradients (e.g., Tomascik and Sanders 1987; Sutherland et al. 2004; Fabricius et al. 2005, 2012; Dikou and van Woesik 2006; Kline et al. 2006; De'ath and Fabricius 2010; Golbuu et al. 2011). In most cases, environmental condition was assumed to have deteriorated; however, such changes were rarely demonstrated. At the scale of regions (10's of km), evidence for the degradation of coral communities as a consequence of chronic eutrophication has remained difficult to demonstrate (Fabricius 2005).
Coral reefs in the inshore area of the Great Barrier Reef, Australia (GBR), are situated in naturally turbid waters, as fine terrigenoclastic sediment is continuously resuspended by prevailing south-easterly winds and tidal currents (Larcombe et al. 1995, 2001; Wolanski et al. 2005; Orpin and Ridd 2012). In addition, suspended solids, nutrients, pesticide residues and other contaminants are delivered by catchment runoff during seasonal flooding of adjacent rivers (Devlin and Brodie 2005; Devlin and Schaffelke 2009; Brodie et al. 2010) and reach the inshore reefs (McCulloch et al. 2003; Jupiter et al. 2008; Kennedy et al. 2012; Bainbridge et al. 2012; Devlin et al. 2012). Since European colonisation, the loads of sediment, total nitrogen and total phosphorus transported to the coastal GBR as runoff are estimated to have increased by factors of 5.5, 5.7 and 8.9, respectively (Kroon et al. 2012). These additional pollutant fluxes accumulate in the inshore environment contributing to the turbidity and nutrient stocks for periods of months to years (Luick et al. 2007; Wolanski et al. 2008; Lambrechts et al. 2010; Andutta et al. 2011; Brodie et al. 2012; Fabricius et al. 2013), and have been implicated in the decline of inshore coral communities (Brodie et al. 2012).

Despite clear evidence for differences in coral reef communities that correspond to environmental conditions within the turbid inshore zone of the GBR (van Woesik et al. 1999; Fabricius et al. 2005, 2012; DeVantier et al. 2006; Cooper et al. 2007; De'ath and Fabricius 2010; Browne et al. 2010, 2012; Uthicke et al. 2010), it remains difficult to directly demonstrate that coral communities have changed as a response to increased pollutant fluxes. The lack of baseline data against which current coral communities and water quality can be compared has been problematic. At a small number of locations, palaeoecological data allow comparisons between historical and present-day coral communities. Roff et al. (2013) describe the loss of staghorn Acropora species that persisted for hundreds of years-a change they interpret as resulting from increased sediment and nutrient fluxes as a result of agricultural development on adjacent catchments. In contrast, in very turbid waters Perry et al. $(2008,2009)$ demonstrate the continued persistence of a low diversity community, albeit limited to very shallow water. The discrepancy between these studies may suggest species-specific susceptibilities to changed conditions, or differing degrees of change in conditions between sites.

In this study, we took advantage of a coral community monitoring dataset that captured the transition between two climatically distinct periods; a five-year period of belowmedian river discharge (2002-2006), followed by six year of above-median river discharge (2007-2012). The availability of remotely sensed estimates of total suspended solids (TSS) and chlorophyll- $a(\mathrm{Chl})$ concentrations over 


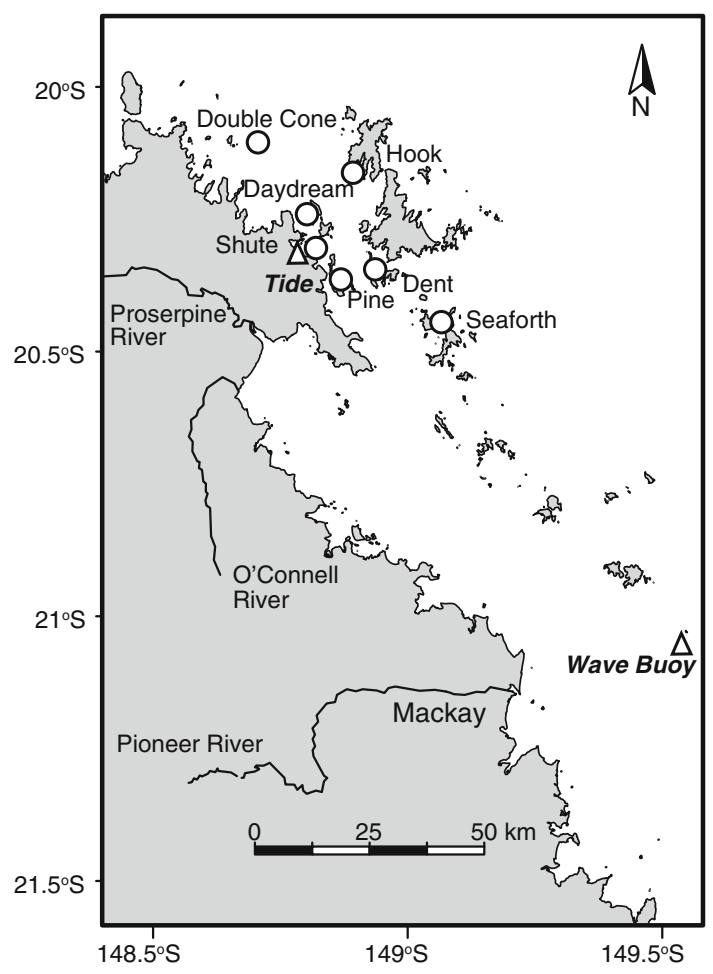

Fig. 1 Map of study area. Location of coral (circles) and environmental (triangles) monitoring locations

this period allowed us to investigate whether increased river runoff resulted in measurable differences in environmental conditions at the regional scale and, if so, how coral communities responded to these changes. We consider the marked increase in river discharge and any observed change in remotely sensed water quality as proxies for increased fluxes of sediments, nutrients and other contaminants from the adjacent catchments. We then focus on coral community dynamics as a way of understanding the responses of coral communities to eutrophication of the inshore GBR. The dataset was explicitly selected because confounding acute disturbances such as severe storms, coral bleaching, or outbreaks of the coraleating crown-of-thorns seastar were largely absent. Over the period of monitoring, the only acute disturbance was Tropical Cyclone Ului in 2009, which caused substantial physical damage to corals at only one of the seven study reefs.

\section{Methods}

Coral community data

Coral community data were collected at seven reefs in the Whitsunday Islands, located within the turbid inner-shelf of the central GBR. Sites were selected at locations at which fringing reefs had developed and were spaced along a gradient of increasing distance from the mouths of regionally significant rivers (Fig. 1). At each location, two sites were selected along contiguous sections of reef slope and separated by at least $250 \mathrm{~m}$. Within each of these sites, five 20-m-long transects were deployed along depth contours at both 2 and $5 \mathrm{~m}$ below lowest astronomic tide (LAT). Transects were permanently marked with steel markers at the mid points and each end. Compass bearings were recorded at each point of inflection to ensure accurate relocation between surveys.

Of the seven reefs, Daydream, Double Cone and Pine were sampled once a year from 2005 to 2012. The remaining four reefs were sampled in 2005 and 2006 and then only every other year: Hook and Shute in 2007, 2009 and 2011, and Dent and Seaforth in 2008, 2010 and 2012 (Fig. 1). Sampling was conducted opportunistically during periods of calm weather and occurred in May (2006, 2011), June (2007, 2008, 2010), July (2005) and was split between May and July in 2009 and 2012. Only the disease data were used from 2005 surveys, as slight inconsistencies in methodology between the first survey in 2005 and subsequent surveys precluded the use of cover and juvenile coral estimates. The cover of major benthic groups for each transect was estimated using the photo point-intercept method developed by the Australian Institute of Marine Science (AIMS) for monitoring of coral reef communities (Jonker et al. 2008). In brief, digital images capturing a nominal $0.1 \mathrm{~m}^{2}$ of substrate were taken at $50-\mathrm{cm}$ intervals, and the benthos falling below five evenly spaced points identified. Only the estimates of hard coral cover were included in this analysis, with corals consistently identified to genus.

The abundance of juvenile corals $(<10 \mathrm{~cm}$ in diameter $)$ was counted within $34-\mathrm{cm}$-wide (dive slate width) transects co-located with the point-intercept transects. Annual sampling was conducted at least five months after the major summer spawning period on the GBR, and most juveniles surviving settlement and early postsettlement mortality were expected to have attained a size available to observation. Care was taken to exclude colonies considered to have resulted from the partial mortality or fragmentation of larger colonies. Possible inconsistencies in taxonomic differentiation of very small corals necessitated the pooling of some genera into the following four groups: Favia, Montastrea, and Barabattoia; Favities and Goniastrea; Lobophyllia, Symphyllia, and Scolymia; Echinophyllia and Oxypora. In each case, these groups combine genera from the same family and species with similar traits; for species in these groups included in Darling et al. (2012), all were classified as stress tolerant. For convenience, when these 
taxonomic groups are referred to in following sections, only the most abundant genus within each group is named.

Instances of coral mortality were recorded within a 2-mwide belt along each transect following the 'scuba search method' developed by AIMS (Miller 2003). For each colony suffering recent or partial mortality, the cause of mortality was classified as either: 'white syndrome' where ongoing mortality and tissue necrosis or discoloration at the tissue/skeleton interface was observed, 'brown band' or 'skeletal eroding band' where ciliates were observed, 'atramentous necrosis' where tissue was being decomposed by sulphur-reducing bacteria (Jones et al. 2004), 'sedimentation' where tissue beneath sediment deposits was in a state of decomposition, or 'unknown' where no obvious cause could be determined or entire colonies were recently dead. In practice, there was a continuum between colonies classified as either 'atramentous necrosis' or 'sedimentation', and these were grouped prior to analysis and hereafter referred to as 'sediment damage'.

\section{Environmental data}

$\mathrm{Chl}$ and TSS estimates were extracted from daily MODISAqua satellite observations from a square of nine, $1-\mathrm{km}^{2}$ pixels located in optically deep waters as closely adjacent to coral sampling locations as possible. The average values of $\mathrm{Chl}$ and TSS estimated from these nine pixels constituted daily estimates over the period 2002-2012 for each reef.

Chl and TSS concentrations were derived using a regionally adapted physics-based ocean colour algorithm (Brando et al. 2012; Schroeder et al. 2007, 2012). This was necessary because of the significant contribution of terrestrial dissolved and particulate organic matter in the water column, resulting in the frequent failure of MODIS standard ocean colour algorithms (Qin et al. 2007). Recent validation results across the entire GBR using ground observations collected within $\pm 3 \mathrm{~h}$ to the satellite measurements showed that for individual points, the error for the retrieval of $\mathrm{Chl}$ and TSS from the regionally adapted algorithm was \pm 90 and $70 \%$, respectively, compared to errors exceeding $240 \%$ for MODIS standard Chl and TSS products.

Algorithm performance could not be evaluated in a similar fashion for our study region due to an insufficient number of coincident in-situ and satellite observations. However, for TSS, we had access to two additional datasets that allowed us to evaluate the magnitude of MODISderived TSS to that observed at the reef sites. At three of the study reefs (Daydream, Double Cone and Pine; Fig. 1), WETLabs Eco FLNTUSB turbidity sensors were deployed at the 5-m-deep coral sites from 2007 onward and recorded turbidity (in nephelometric turbidity units, NTU) at 10-min intervals. At these same reefs, water samples were collected close to the sensors and from the surface, mid water and near-bottom of the water column within $250 \mathrm{~m}$ of the reef at approximately 4-month intervals, again from 2007 onward, from which $\mathrm{TSS}_{\mathrm{f}}$ (total suspended solids, filtered) data were derived. The MODIS-derived TSS estimates were then evaluated by substitution of terms between model 2 regressions (Legendre and Legendre 1998) of MODIS TSS with NTU and TSS $_{\mathrm{f}}$ with NTU.

To relate variability in TSS to river discharge, TSS estimates were first standardised for the influence of wave and tidal conditions at the time of sampling. Tidal range estimates were the difference between the daily maximum and minimum in observed sea level values from tide gauge data supplied by the Queensland Department of Transport and Main Roads (Fig. 1). Mean wave height for each day and the three days preceding observations of TSS were calculated from wave-buoy recordings provided by the Queensland Department of Environment and Heritage Protection (Fig. 1).

Daily discharge volumes of the Proserpine, O'Connell and Pioneer rivers were obtained from the Queensland Department of Natural Resources and Mines. These three rivers enter the ocean to the south of the study area (Fig. 1), with plumes merging to become indistinguishable from each other at the study locations (Brodie et al. 2012; Schroeder et al. 2012). As a point of reference, long-term median discharges were estimated from records from 1967 to 2000 (Proserpine River), 1971-2000 (O'Connell River) and 1979-2000 (Pioneer River).

The proportion of reef sediments with grainsizes $<63 \mu \mathrm{m}$ was estimated from five 1-cm-deep sediment cores collected from available surface deposits along each 5-m-deep coral site at the time of coral surveys. The grainsize distributions of the samples were estimated by MALVERN laser analysis of the portion of samples that passed through a 1-mm sieve.

\section{Data analysis}

Chl and TSS data were explored graphically to identify the duration of influences attributable to river discharge. The relationships between observed Chl and TSS over these identified periods and the discharge of local rivers were assessed with generalised additive mixed models (GAMM; Wood 2006). The mean concentrations of Chl and TSS for each reef and each year were modelled against the cumulative discharge from the beginning of the water year ( 1 October) to the end of April for Chl, and to the end of June for TSS. To account for the inherent auto-correlation of means from the same locations, a random-effect term 'reef' was included. As turbidity is strongly influenced by resuspension, the TSS estimates included in the GAMM 
were first standardised for the predictable influence of resuspension by separately fitting generalised additive models (GAM; Wood 2006) including terms for 'tidal range', 'average wave height' and 'average wave height over the preceding 3 days to the TSS observations for each reef.

The influence of environmental conditions on variation in the coral community attributes: density of juvenile corals, coral cover and disease incidence was investigated with linear models. For each community attribute, reeflevel means were modelled against the three environmental variables: mean Chl, mean TSS and mean proportion of fine sediment. Model selection based on Akaike's information criterion values was used to identify any environmental variable contributing to the variation in the coral community attributes between reefs.

Differences in univariate community attributes between depths were assessed with linear mixed-effects models (LME; Pinheiro et al. 2013) applied to data averaged to reef and depth. Models included a random-effect term for reef to account for auto-correlation between communities at the same reef.

Changes in coral community attributes over the study period were investigated using separate GAMMs, applied to each attribute and depth. For coral cover and juvenile coral densities, these GAMMs included a term for year and random term for reef. No additional terms for environmental variables were included as both coral cover and juvenile density are the result of processes operating over several years. For coral disease, separate models including terms for annual estimates of Chl, TSS or the proportion of sediments with grainsizes less than $63 \mu \mathrm{m}$ were assessed. For these analyses, Chl was averaged over the months of February-April while TSS was averaged over the months of March-May. This period was one month shorter than the period when TSS was identified to be influenced by runoff (March-June) and was used because in several years the disease surveys were completed in May. For each reef and depth combination, disease incidence was scaled to a distribution with a mean $=0$ and a standard deviation $=1$ to account for differences in disease susceptibility because of compositional differences between communities.

Analyses of multivariate genus-level juvenile and coral cover data were based on Bray-Curtis dissimilarities between square-root-transformed observations (Bray and Curtis 1957). The unconstrained structure in communities was visualised in bi-plots of reef and genus scores against the first two axis of principal coordinates analyses (PCoA; Legendre and Legendre 1998). The influence of depth, Chl, TSS and sediment grainsize composition was analysed with permutational MANOVA models (Anderson 2001), fitted separately for each combination of environmental variable and community type. For these analyses, community data and environmental variables were averaged over years to avoid any issues of auto-correlation between observations from the same reefs. As the focus was on consistent changes in community composition rather than abundance, as investigated by univariate analyses, data were standardised by dividing the transformed genus-level abundances by the sum of the transformed abundances for that reef. When permutational MANOVA tests indicated the significant influence of an environmental parameter, canonical analyses of principal coordinates (CAP; Anderson and Willis 2003) were used to identify genera corresponding to those environmental conditions. Change in community composition through time was analysed by permutational MANOVA including a term for year and with permutations limited to occur within reefs. Genera demonstrating correlations with time were identified on the basis of their scores against the canonical axis of a partial CAP, which first removed spatial variability in community composition attributed to different reefs (Oksanen et al. 2013).

\section{Results}

Influence of river discharge on water quality

The combined long-term median annual discharge of the O'Connell, Proserpine and Pioneer Rivers was 518 GL. From 2002 to 2006, discharge was consistently below this median, while from 2007 to 2012 discharge was well above the median (Fig. 2). It was on the basis of this difference that we categorised the pre-2007 years as 'Dry' and 2007 to 2012 as 'Wet'.

Remotely sensed TSS and Chl concentrations, while variable, were seasonally high during and following the summer wet season (Fig. 3). Over the months February to April, the mean wet period $\mathrm{Chl}$ concentration was $0.53 \mu \mathrm{g}^{-1}$ and $31 \%$ higher than during the dry period. Over the months March to June, the wet period TSS was $1.47 \mathrm{mg}^{-1}$ and $51 \%$ higher than during the dry period. Simultaneous solving of model 2 regressions: $\log (\mathrm{TSS})=$ $-0.026+1.0628 * \log (\mathrm{NTU}) \quad$ with $R^{2}=0.54$, and $\log \left(\mathrm{TSS}_{\mathrm{f}}\right)=0.27+1.1 .216 * \log (\mathrm{NTU}) \quad$ with $R^{2}=0.76$, demonstrated that $\mathrm{TSS}_{\mathrm{f}}$ sampled close to the reef was higher than TSS estimated from MODIS in open water. Wet period $\mathrm{TSS}_{\mathrm{f}}$ was estimated at $2.17 \mathrm{mg} \mathrm{l}^{-1}$ with $95 \%$ confidence intervals of 1.75 to $2.62 \mathrm{mg} \mathrm{l}^{-1}$.

Both TSS and Chl concentrations showed a significant relationship with river discharge (Fig. 4a, b). The relationship between TSS and discharge levelled out at the extremely high discharge values observed during 2011 (Fig. 4a). It is important to note that TSS was standardised prior to analysis to remove any predictable influence of 


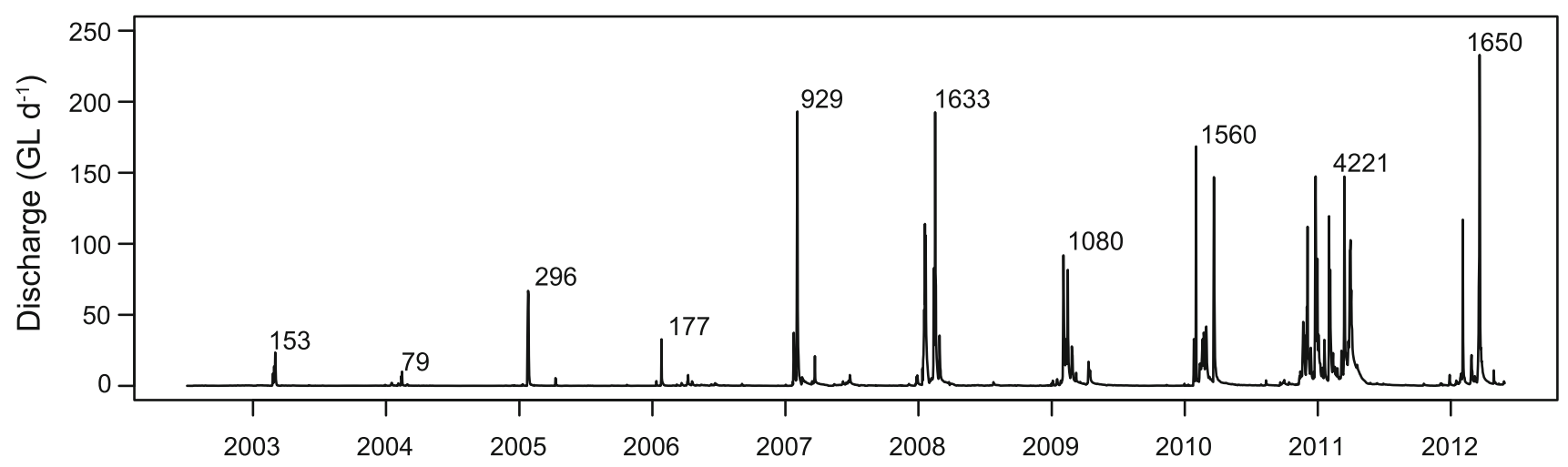

Fig. 2 Combined daily discharge of the O'Connell, Pioneer and Proserpine Rivers. Numbers indicate the total annual discharge (GL) based on water years (1 October-31 September)

Fig. 3 Seasonal trends in MODIS-Aqua satellite observations for a total suspended solids (TSS) and b chlorophyll- $a(\mathrm{Chl})$. For each calendar month, unfilled boxes include data from the dry period (2002-2006) and filled boxes the wet period (2007-2012). Boxes include the median and second and third quartiles of the data; whiskers extend to twice the interquartile range

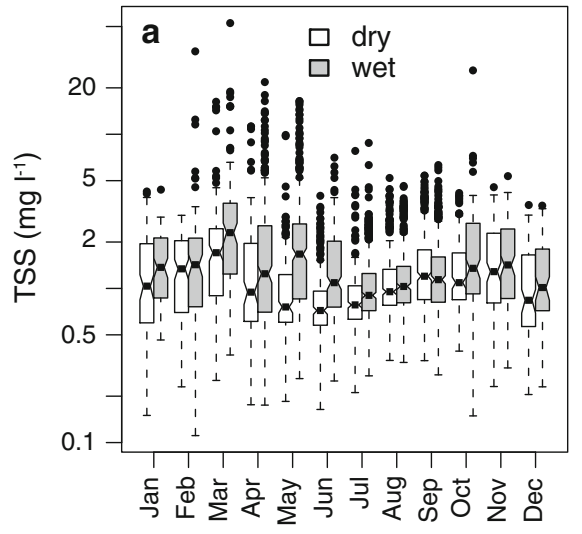

wave height or tidal range that, in combination, explained between 21 and $32 \%$ of the variation in TSS observed at the seven study reefs.

Variation in environmental conditions between reefs

The environmental conditions at the study reefs were characterised by the two water quality parameters (TSS and Chl) and by the grainsize of sediments. TSS and Chl were significantly different between reefs; however, these differences were relatively small compared to the temporal variability within the reefs (Fig. 5a, b). For TSS, contrasting means for each reef against Daydream indicated higher levels at Pine $(p<0.001)$ and lower levels at Hook $(p<0.001)$, Double Cone $(p<0.001)$ and Seaforth $(p=0.011)$. For Chl, Double Cone $(p=0.005)$, Hook $(p<0.001)$ and Seaforth $(p=0.025)$ had lower mean concentrations than Daydream. These differences in mean conditions between reefs only accounted for $7 \%$ (TSS) and $3 \%$ (Chl) of the overall variability observed. In contrast, between-reef differences in the proportion of sediment with a grainsize $<63 \mu \mathrm{m}$ accounted for $72 \%$ of the variability in that dataset. Double Cone $(p=0.006)$, Hook $(p=0.001)$ and Seaforth $(p=0.005)$ had a lower proportion of sediment with grainsize $<63 \mu \mathrm{m}$ than Daydream; the grainsize distributions at the remaining reefs did not differ from Daydream (Fig. 5c).

Separate linear models relating the reef-level mean for each of the three environmental variables to the coral community attributes of mean coral cover and mean juvenile density at each of the 2 and $5 \mathrm{~m}$ depths revealed no relationships ( $p>0.1$ for all 12 models).

Variation in coral reef community attributes

Over the period of our study, the density of juvenile corals declined (Fig. 6a, b). In contrast, there was no consistent trend in coral cover (Fig. 6c, d). At $2 \mathrm{~m}$ depth, there was a rapid increase in coral cover at Double Cone and Shute between 2010 and 2012. These increases largely reflect changes in the cover of Acropora that accounted for $80 \%$ of the increase in cover from 33 to $46 \%$ at Double Cone and $74 \%$ of the increase in cover from 35 to $43 \%$ at Shute. In contrast, the decline in cover at both depths at Daydream was almost entirely due to reductions in cover of branching Acropora species as a result of damage incurred 


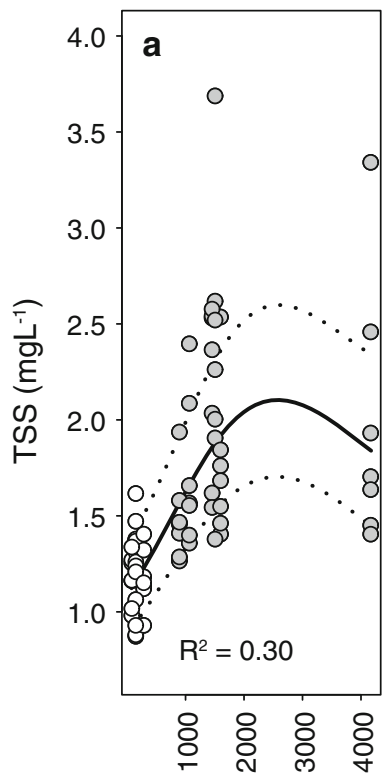

River discharge to June (GL)

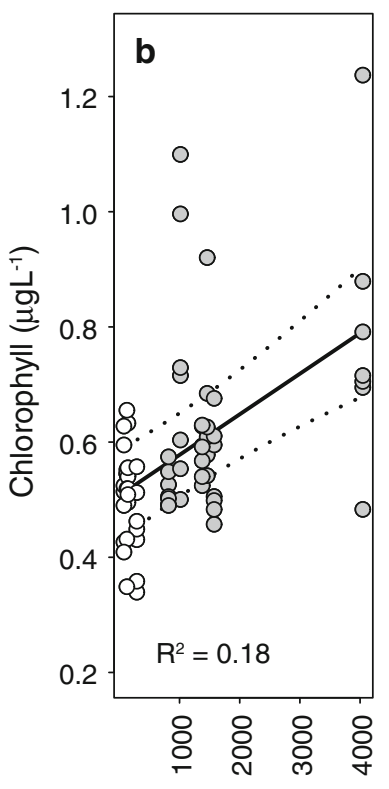

River discharge to April (GL)

Fig. 4 Water quality relationships with river discharge, a total suspended solids (TSS) in the months March-June, b chlorophyll$a$ (Chl) in the months February-April. River discharge is the cumulative flow since October of the previous year to, a June, b April. Open circles include data from the dry period (2002-2006) and filled circles the wet period (2007-2012). TSS was standardised for the influence of waves and tidal range. Estimated trends derived from generalised additive mixed model analysis are indicated by bold lines, bounded by the $95 \%$ confidence intervals of those trends (dotted lines)

during the passage of Tropical Cyclone Ului in early 2009. At all other sites, only minimal changes in cover were observed.

\section{Variation in coral disease}

The incidence of disease varied among reefs (Table 1); 'white syndrome' at $5 \mathrm{~m}$ depth was positively correlated with the proportions of fine-grained sediments $(p=0.001$, $R^{2}=0.88$ ) while 'unknown scarring' was more prevalent on reefs with high proportions of fine-grained sediments at both $2 \mathrm{~m}\left(p=0.017, R^{2}=0.65\right)$ and $5 \mathrm{~m}(p=0.038$, $R^{2}=0.53$ ) depths. The distributions of 'white syndrome' and 'unknown scarring' show broad similarities, and as there is potential inconsistency in the differentiation between these classifications, we have combined the response of these for presentation (Fig. 7a). The relationship between both 'white syndrome' and 'unknown scaring' with fine sediments was primarily driven by high incidences at the two reefs with highest cover of branching growth forms of the genus Acropora: $5 \mathrm{~m}$ depths at Daydream (mean Acropora cover $25.4 \%$ ) and Dent (mean Acropora cover $12.3 \%$ ). The combined category 'sediment damage' at $5 \mathrm{~m}$ depth was positively associated with TSS concentration ( $p=0.018$; Fig. 7b). This relationship was strongly influenced by the highest disease incidence at the most turbid site, Pine Island, where corals are mostly of massive or laminar growth form and accumulation of sediment onto living corals was observed over a wide range of genera.

The highest incidence of disease was observed in 2007 and 2008 (Fig. 8a), reflecting the high incidence of 'white syndrome', 'brown band disease', 'unknown scaring' and 'skeletal eroding band' variously among reefs (Fig. 8b-e). Overall, incidence of disease was higher in 2007 than in either $2005(p=0.009), 2006(p=0.018)$ or 2009 $(p=0.02)$. This maximum was coincident with the

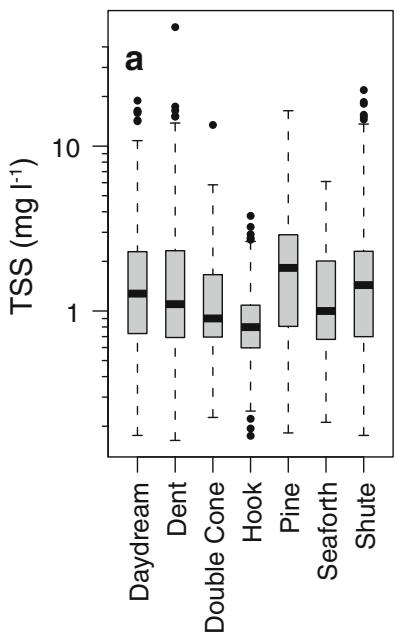

Fig. 5 Environmental variables at study reefs, a total suspended solids (TSS; March-June), b chlorophyll- $a$ (Chl; February-April) and c proportion of sediments with grainsizes $<63 \mu \mathrm{m}$. Boxes represent
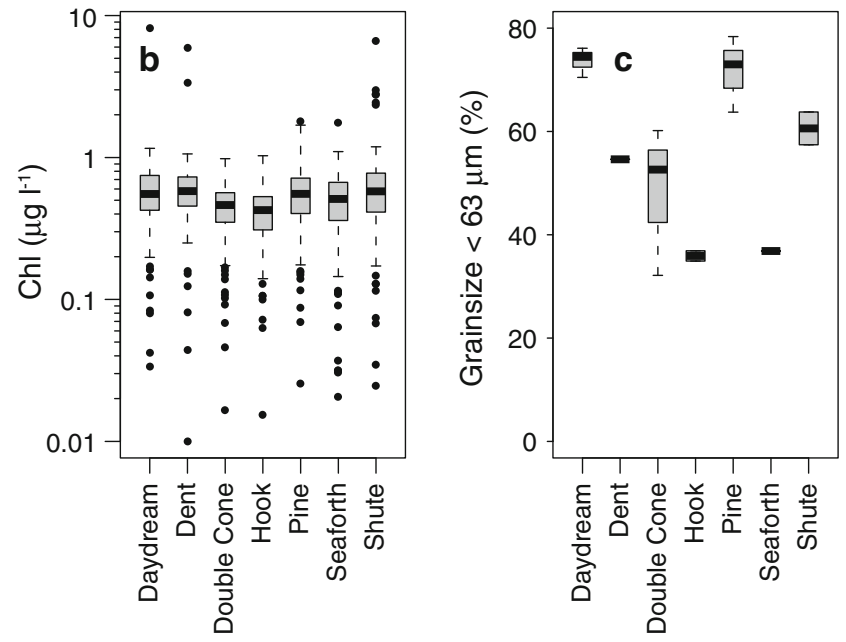

the median and second and third quartiles of all observations of TSS and Chl from 2003 to 2012 and from 2007 to 2012 for Grainsize; whiskers extend to twice the interquartile range of the data 

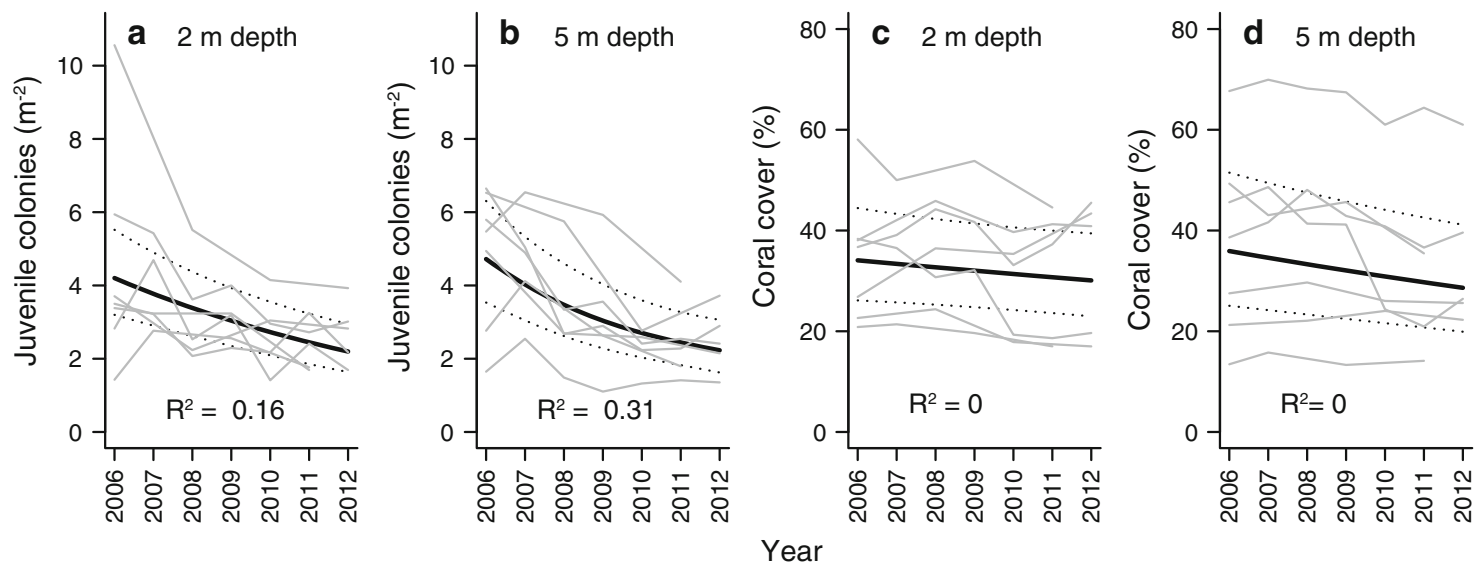

Fig. 6 Temporal changes in coral communities: a juvenile density at $2 \mathrm{~m}$, b juvenile density at $5 \mathrm{~m}$, c coral cover at $2 \mathrm{~m}$, and $\mathbf{d}$ coral cover at $5 \mathrm{~m}$. Estimated trends derived from generalised additive mixed

model analysis are indicated by bold lines, bounded by the $95 \%$ confidence intervals of those trends (dotted lines). Grey lines represent observations for individual reefs

Table 1 Incidence of coral disease

Values are the number of colonies observed within $400 \mathrm{~m}^{2}$ belts (sum of the ten $40 \mathrm{~m}^{2}$ transects at each depth) averaged over all observations between 2005 and 2012

\begin{tabular}{llllccc}
\hline Reef & $\begin{array}{l}\text { Depth } \\
(\mathrm{m})\end{array}$ & $\begin{array}{l}\text { Brown } \\
\text { band }\end{array}$ & $\begin{array}{l}\text { Skeletal eroding } \\
\text { band }\end{array}$ & $\begin{array}{l}\text { Sediment } \\
\text { damage }\end{array}$ & $\begin{array}{l}\text { Unknown } \\
\text { scarring }\end{array}$ & $\begin{array}{l}\text { White } \\
\text { syndrome }\end{array}$ \\
\hline Daydream & 2 & 4.4 & 0.1 & 0.5 & 19.8 & 4.1 \\
& 5 & 2.5 & 0.5 & 3.2 & 22.5 & 23.2 \\
Dent & 2 & 2.4 & 1.6 & 0.2 & 15.6 & 7 \\
& 5 & 4.2 & 1 & 1.8 & 15.8 & 9.6 \\
Double & 2 & 0.5 & 0.5 & 1 & 11.2 & 3.1 \\
cone & 5 & 0.1 & 1.6 & 1.8 & 12.4 & 2 \\
Hook & 2 & 0.6 & 1.2 & 0.4 & 5.4 & 0.8 \\
& 5 & 0 & 0 & 1.4 & 2.4 & 0.8 \\
Pine & 2 & 0.2 & 0.1 & 7.9 & 13.1 & 4.9 \\
& 5 & 0.5 & 0.2 & 14.2 & 9.9 & 6 \\
Seaforth & 2 & 0 & 0 & 0 & 4.6 & 0.4 \\
& 5 & 0 & 0 & 0.2 & 5.6 & 0.8 \\
Shute & 2 & 0.2 & 0.6 & 1.8 & 7 & 2 \\
& 5 & 0.4 & 0 & 4.8 & 8.6 & 2.4 \\
\hline
\end{tabular}

transition from the Dry to the Wet climactic period. Subsequent observations indicated no further increase in disease despite higher river discharges in subsequent years (Fig. 2). Relationships between disease incidence and changes in environmental conditions were only observed between the 'sediment damage' categorisation and both total discharge (at $5 \mathrm{~m} p=0.002, R^{2}=0.18$; at $2 \mathrm{~m}$ $p=0.002, R^{2}=0.15$ ) and mean TSS (at $5 \mathrm{~m} p<0.001$, $R^{2}=0.19 ;$ at $\left.2 \mathrm{~m} p=0.01, R^{2}=0.1\right)$.

Responses of coral community composition to changes in water quality

The composition of coral communities differed both between reefs and between depths within reefs (Fig. 9). Constrained analyses found no strong relationship between juvenile community composition and environmental conditions (Tables 2, 3). Rather, the spread of observations from each reef-depth combination in the unconstrained analysis demonstrates the variability in the composition of juvenile assemblages through time (Fig. 9a; Table 2). The genera identified as declining most consistently over the period of the study (Table 3) were largely aligned with the first principal coordinate, demonstrating that changes in composition of communities over the period of the study were more consistent than, or aligned with, any unresolved environmental variable structuring these assemblages (Fig. 9b). The second principal coordinate aligns with those genera showing the most consistent variation with depth (Fig. 9b; Table 3).

In contrast to the juvenile communities, the composition of coral cover at each reef was less temporally variable 

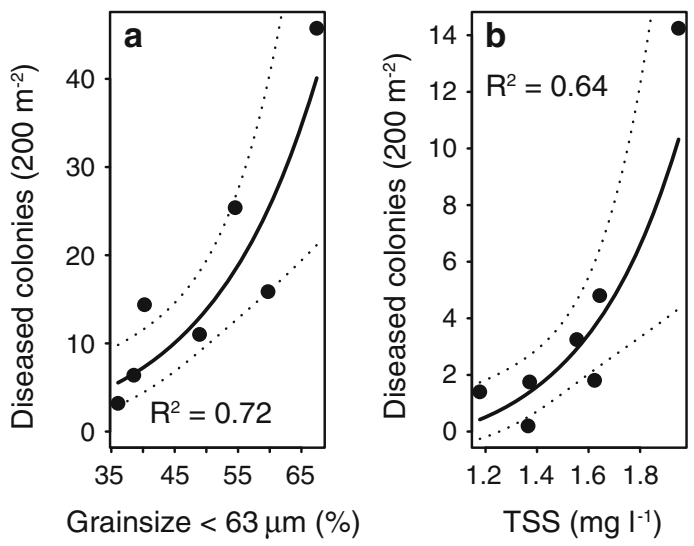

Fig. 7 Variation in disease incidence attributable to environmental conditions of a sediments with grainsizes $<63 \mu \mathrm{m}$ on the combined incidence of 'white syndrome' and 'unknown scarring' at $5 \mathrm{~m}$ depth and of $\mathbf{b}$ total suspended solids (TSS) on the combined incidence of 'sediment damage' at $5 \mathrm{~m}$ depth

(Fig. 9c; Table 2). Acropora was the only genus to show a consistent decline over the period of the study, and this was more pronounced at $5 \mathrm{~m}$ than at $2 \mathrm{~m}$ depths (Table 3). The first principal component strongly aligned with the cover of Acropora and Goniopora, the genera that most influenced the observed difference in composition between depths (Table 3). The composition of coral cover also varied in response to differences in TSS concentration ( $5 \mathrm{~m}$ only) and the proportion of fine-grained sediments in reefal substrata (Table 2). In contrast to Acropora and Goniopora, the remaining genera showing relationships to TSS and the sediment composition (Galaxea, Pavona, Pectinia and Porites; Table 3) were aligned with the second principal component of the unconstrained ordination (Fig. 9d).

\section{Discussion}

The change between a period of below-median discharge to a period of above-median discharge and flooding of local rivers resulted in higher Chl and TSS concentrations and concomitant coral community responses. Our observations were consistent with the general concept that variable selection pressure along environmental gradients influences the composition of coral communities. However, the variability in response among reefs reiterates some of the issues that limit a clear demonstration of coral community responses to chronic eutrophication at regional scales.

Short time series of turbidity document the strong influence of wave-driven resuspension on turbidity in coastal waters of the GBR (Larcombe et al. 1995), leading to ongoing debate as to the magnitude of influence that any additional flux of materials from rivers could have on the

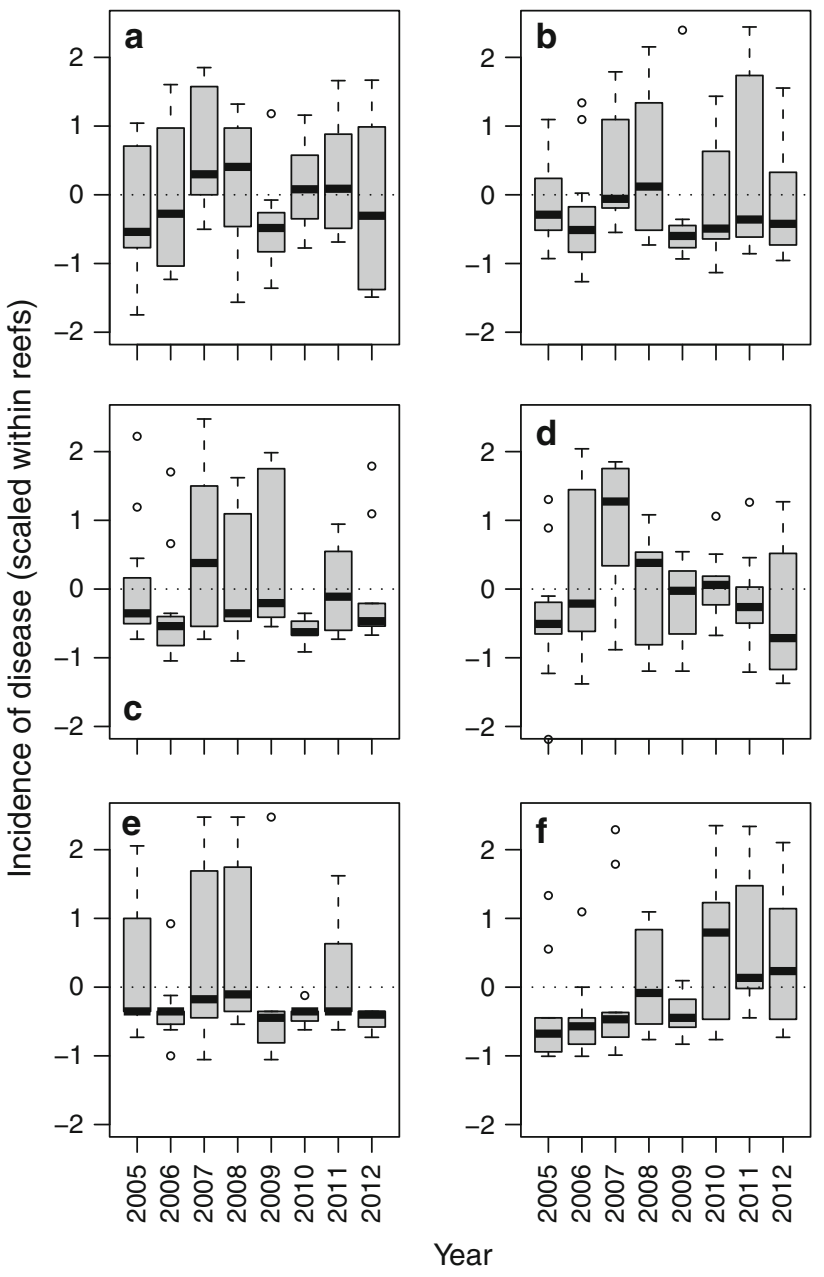

Fig. 8 Relative incidence of coral disease categories over time: a sum of all categories, b 'white syndrome', c 'brown band disease', d 'unknown scarring', e 'skeletal eroding band', and f 'sediment damage'. Disease incidence is scaled to a mean of zero and standard deviation of one within each reef

conditions experienced by corals (Orpin and Ridd 2012). For the Whitsunday Region, the decade-long MODIS-Aqua time series demonstrated that $\mathrm{Chl}$ and TSS concentrations in waters surrounding inshore coral reefs were influenced by river discharge. The prolonged (months) elevation of TSS supports emerging evidence that flood-derived fine sediments are retained within the inshore GBR (Lambrechts et al. 2010; Fabricius et al. 2013), as shown elsewhere (Draut et al. 2009), and add to turbidity as a result of repeated resuspension until being winnowed away by wave and tidal activity (Storlazzi et al. 2009). The demonstrated relationship between discharge of local rivers and Chl reiterates the relationship between runoff and the availability of nutrients in coastal waters (Furnas et al. 2005, 2011; Wooldridge et al. 2006).

The exposure of corals to stressful conditions associated with a higher concentration of TSS varies as a result of 

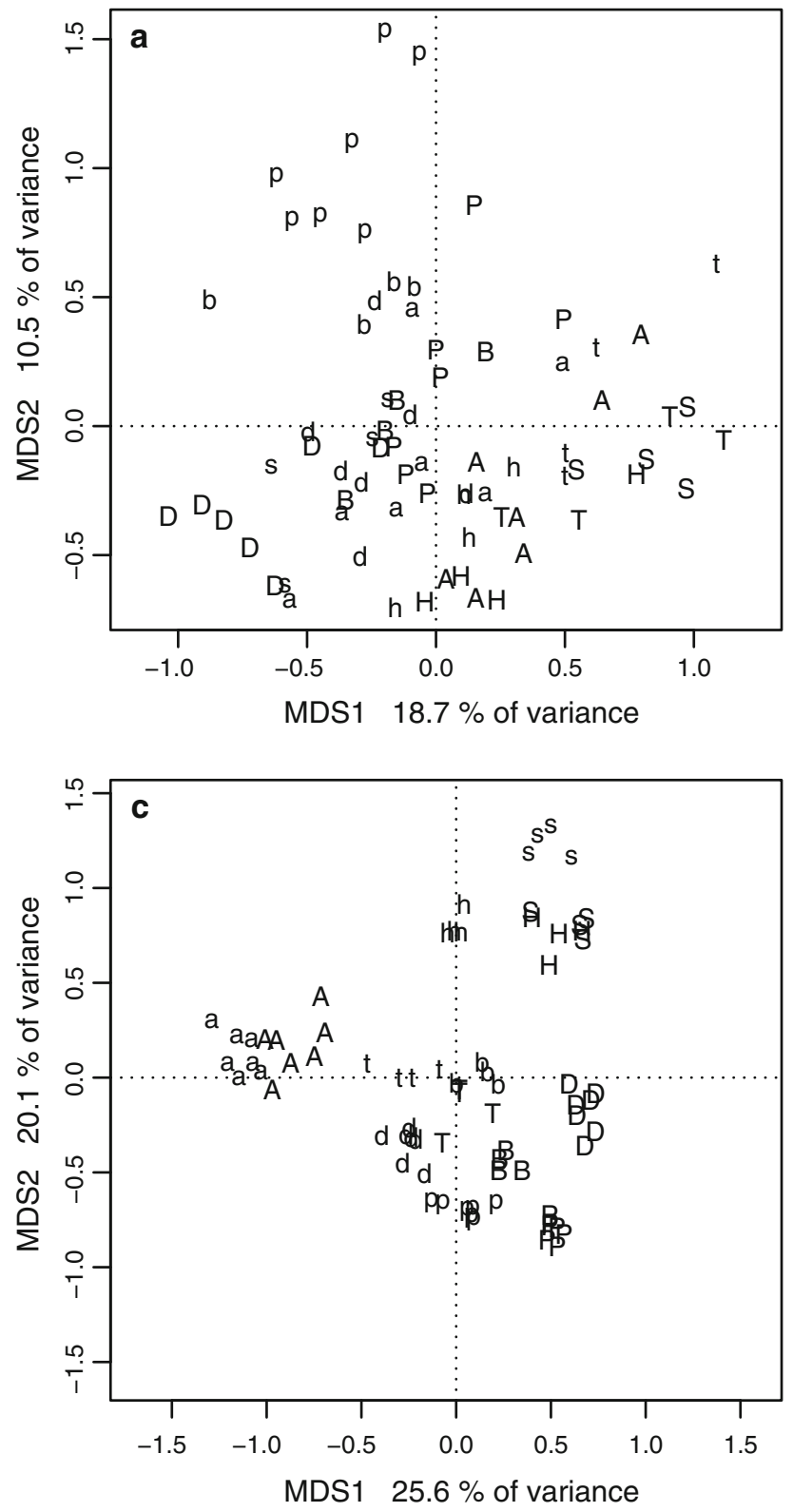

Fig. 9 Unconstrained principal coordinates biplots of coral communities for: juveniles $(\mathbf{a}, \mathbf{b})$ and cover $(\mathbf{c}, \mathbf{d})$. For clarity, site scores and genus vectors are presented in separate panels. Letters in site-level ordinations (a, c) differentiate the seven study reefs (A: Daydream, B: Dent, D: Double Cone, H: Hook, P: Pine, S: Seaforth and T: Shute),

interactions between local hydrodynamics and depth as determinants of rates of sedimentation and light attenuation (Wolanski et al. 2005; Storlazzi et al. 2009), but also the susceptibility of the corals present (Rogers 1983; Erftemeijer et al. 2012). While teasing apart such fine-scale processes was beyond the scope of our data, in general it could reasonably be assumed that observed increases in TSS would have resulted in both an increased sediment flux and reduction in light at the substrate level. Light attenuates in water exponentially as a function of the light
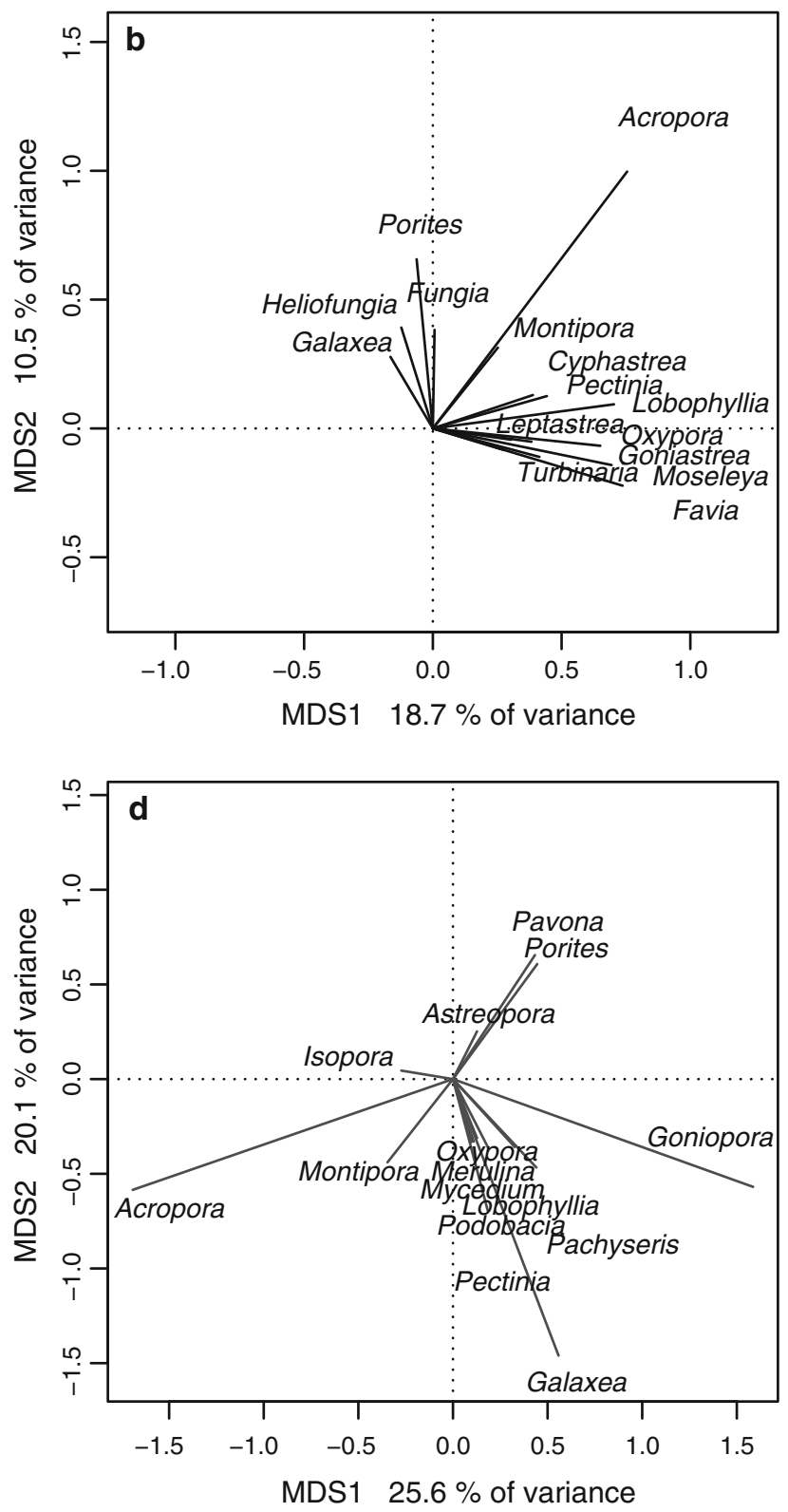

upper case indicate $5 \mathrm{~m}$ depth communities, and lower case $2 \mathrm{~m}$ depth communities. Of the 53 genera of juvenile corals and 49 genera for which cover estimates were analysed, only those with absolute scores of 0.2 or greater against either the first or second principal coordinates are presented $(\mathbf{b}, \mathbf{d})$

attenuation coefficient of the water and depth in metres, with the type and concentration of suspended matter influencing the light attenuation coefficient of turbid waters (Van Duin et al. 2001). For three of the reefs monitored in this study, Cooper et al. (2007) estimate attenuation coefficients, the mean of which was 0.2055. Using this attenuation coefficient at mid-tide (LAT $+1.5 \mathrm{~m}$ ), our 2-m sites would receive $49 \%$ of surface irradiation and our 5-m sites $26 \%$, demonstrating the potential stress associated with reduced light availability over even this small depth range. 
Table 2 Results of permutational MANOVA of the responses of coral community attributes to depth, water quality and time

\begin{tabular}{|c|c|c|c|}
\hline Depth & $F($ model $)$ & $R$-square & $P(>F)$ \\
\hline Juveniles & 1.681 & 0.123 & 0.02 \\
\hline Cover & 1.056 & 0.081 & 0.029 \\
\hline \multicolumn{4}{|c|}{ Chlorophyll $F R$-square $P(>\mathrm{F})$} \\
\hline Juveniles $(2 \mathrm{~m})$ & 1.206 & 0.194 & 0.218 \\
\hline Juveniles $(5 \mathrm{~m})$ & 0.960 & 0.161 & 0.534 \\
\hline Cover $(2 \mathrm{~m})$ & 0.991 & 0.165 & 0.444 \\
\hline Cover $(5 \mathrm{~m})$ & 1.616 & 0.244 & 0.115 \\
\hline \multicolumn{4}{|c|}{ TSS $F R$-square $P(>F)$} \\
\hline Juveniles $(2 \mathrm{~m})$ & 1.037 & 0.215 & 0.125 \\
\hline Juveniles $(5 \mathrm{~m})$ & 0.745 & 0.130 & 0.771 \\
\hline Cover $(2 \mathrm{~m})$ & 1.334 & 0.211 & 0.215 \\
\hline Cover (5 m) & 1.898 & 0.275 & 0.033 \\
\hline \multicolumn{4}{|c|}{ Fine sediment $F R$-square $P(>F)$} \\
\hline Juveniles $(2 \mathrm{~m})$ & 1.039 & 0.172 & 0.398 \\
\hline Juveniles $(5 \mathrm{~m})$ & 1.055 & 0.174 & 0.403 \\
\hline Cover (2 m) & 2.438 & 0.328 & 0.02 \\
\hline Cover (5 m) & 2.183 & 0.304 & 0.009 \\
\hline \multicolumn{4}{|c|}{ Time $F R$-square $P(>F)$} \\
\hline Juveniles (2 m) & 1.703 & 0.046 & 0.001 \\
\hline Juveniles $(5 \mathrm{~m})$ & 3.810 & 0.098 & 0.001 \\
\hline Cover $(2 \mathrm{~m})$ & 0.523 & 0.015 & 0.052 \\
\hline Cover $(5 \mathrm{~m})$ & 0.461 & 0.013 & 0.047 \\
\hline
\end{tabular}

Each row represents a separate analysis of log-transformed genuslevel observations of mean coral cover or juvenile density over the years 2006-2012 from each reef and depth sampled. Depth was a categorical variable differentiating communities at 2 and $5 \mathrm{~m}$ below lowest astronomical tide. The other environmental variables were averaged over all available data from each reef

The partial contribution of TSS to the attenuation coefficient is variable within the literature; however, the value of 0.067*TSS reported by Devlin et al. (2008) is within the bounds of those reported elsewhere (e.g., Van Duin et al. 2001). Using this partial contribution of TSS to adjust the attenuation coefficient implies a further reduction of surface light to $\sim 20 \%$ at our 5-m sites as result of the proportional increase in TSS we observed. This level of surface light attenuation is approaching the limit for reef development of 6-8\% reported by Cooper et al. (2007), and the lower limit for corals in general in the range of 2-8 \% reported by Titlyanov and Latypov (1991). In combination, the observed increases in Chl and TSS demonstrate the increased exposure of these reefs to catchment-derived contaminants, including the likelihood for exposure to other contaminants such as pesticides that, while not measured here, have been shown to correlate to runoff within the GBR (Kennedy et al. 2012).

The influence of the 'first flush' of the rivers in this region was evident in our coral disease records with disease incidence at a maximum in 2007 , following the first drought-breaking rains after a period of dry years. The timing of maximum disease incidence demonstrates the selective pressures associated with environmental extremes, with susceptible colonies that had persisted during conditions of lower $\mathrm{Chl}$ and TSS concentrations dying as water quality declined. This conclusion is supported by reports of increased disease prevalence in response to stress associated with floods, increased nutrient availability and sedimentation (Bruno et al. 2003; Haapkyla et al. 2011, 2013; Lesser et al. 2007; Weber et al. 2006, 2012; Vega Thurber et al. 2014).

The absence of a continued increase in coral disease at higher river discharges was consistent with our observations of a levelling of the relationship between TSS and discharge. Rivers' TSS loads may be decoupled from discharge volume as a result of the timing of peak flows within individual wet seasons or within longer-term climatic cycles that alter the availability of erodible and mobile sediment within the catchments (e.g., Kuhnert et al. 2012). The peak discharge occurred in 2011 after four years of above-median flows, which is likely to have flushed out available sediments that had accumulated during the preceding dry period as well as resulting in higher vegetation cover in the catchments, thus reducing the availability of sediments to erosional processes. A further consideration is that susceptible colonies had died on first exposure to sufficiently stressful conditions, resulting in the remaining community being less susceptible to subsequent exposure to similar conditions. Our estimates of disease incidence were potentially confounded by the slight seasonal differences in the timing of surveys. The three years 2005, 2009 and 2012 for which sampling was undertaken in July returned the lowest overall precedence of disease, a result consistent with lower winter prevalence of 'ulcerative white spots' and 'white syndrome' (Haapkyla et al. 2010) and of 'atramentous necrosis' (Jones et al. 2004), though contrasting with a higher incidence of 'brown band disease' in winter (Haapkyla et al. 2010). However, we also observed a similarly low incidence of disease during the earliest sampling of May 2006, detracting from seasonal confounding as an explanation of our observed patterns of disease incidence.

The reduction in density and change in assemblage composition of juvenile corals over the study period was consistent with the well-documented sensitivity of early life-history stages of corals to eutrophication (Fabricius 2005, 2011; Erftemeijer et al. 2012). That the responses of the juvenile communities were more pronounced at $5 \mathrm{~m}$ than at $2 \mathrm{~m}$ depth was consistent with the expected compounding of reduced light availability and increased deposition of sediments with increasing depths (Wolanski et al. 2005; Cooper et al. 2007). This was particularly 
Table 3 Results of canonical analysis of principal coordinates
Coral genera for which juvenile density or cover corresponded to the constraining canonical axis for each analysis are presented along with their weightings on the canonical axis. Only community and environmental variable combinations for which the permutational MANOVA indicated significant effects of environmental variable, $p$ values $<0.05$ (Table 2), are represented. Only genera with weightings $> \pm 0.15$ are included. The sign of the weightings indicates either a positive or negative relationship with the constraining variable

\begin{tabular}{|c|c|c|c|c|c|c|c|c|c|}
\hline \multirow[t]{2}{*}{ Genus } & \multicolumn{2}{|l|}{ Depth } & \multirow{2}{*}{$\begin{array}{l}\text { TSS } \\
\text { Cover } \\
5 \mathrm{~m}\end{array}$} & \multicolumn{2}{|c|}{ Fine sediment } & \multicolumn{4}{|l|}{ Time } \\
\hline & Juveniles & Cover & & $\begin{array}{l}\text { Cover } \\
2 \mathrm{~m}\end{array}$ & $\begin{array}{l}\text { Cover } \\
5 \mathrm{~m}\end{array}$ & $\begin{array}{l}\text { Juveniles } \\
2 \mathrm{~m}\end{array}$ & $\begin{array}{l}\text { Juveniles } \\
5 \mathrm{~m}\end{array}$ & $\begin{array}{l}\text { Cover } \\
2 \mathrm{~m}\end{array}$ & $\begin{array}{l}\text { Cover } \\
5 \mathrm{~m}\end{array}$ \\
\hline Acropora & -0.18 & -0.35 & 0.17 & 0.54 & 0.48 & -0.33 & -0.52 & -0.17 & -0.30 \\
\hline Cyphastrea & & & & & & -0.18 & -0.17 & & \\
\hline \multicolumn{10}{|l|}{ Echinopora } \\
\hline Favia & & & & & & -0.15 & & & \\
\hline Fungia & -0.22 & & & & & & & & \\
\hline Galaxea & & & 0.20 & 0.22 & & & & & \\
\hline Goniastrea & & & & & & -0.22 & -0.20 & & \\
\hline Goniopora & & 0.32 & -0.27 & & -0.32 & & -0.22 & & \\
\hline Leptastrea & & & & & & & -0.20 & & \\
\hline Lobophyllia & & & & & & -0.18 & -0.28 & & \\
\hline Montipora & -0.17 & & & & & & & & \\
\hline Moseleya & 0.15 & & & & & & & & \\
\hline \multicolumn{10}{|l|}{ Mycedium } \\
\hline \multicolumn{10}{|l|}{ Oxypora } \\
\hline \multicolumn{10}{|l|}{ Pachyseris } \\
\hline Pavona & & & -0.20 & -0.27 & -0.17 & & & & \\
\hline Pectinia & & & 0.24 & & 0.17 & & -0.31 & & \\
\hline Pocillopora & & & & & & 0.18 & & & \\
\hline Podobacia & & & & & & & -0.18 & & \\
\hline Porites & -0.22 & & -0.29 & -0.29 & -0.18 & & -0.15 & & \\
\hline Turbinaria & & & & & & & & & \\
\hline $\begin{array}{c}\% \text { Variance } \\
\text { explained }\end{array}$ & 37.6 & 29.2 & 27.5 & 32.3 & 30.4 & 10.3 & 17.3 & 4.2 & 4.9 \\
\hline
\end{tabular}

pertinent as our study reefs were located in sheltered locations prone to the accumulation of fine sediments at $5 \mathrm{~m}$ depth: a point demonstrated by high proportions of clay and silt-sized fractions in sediments. Indeed, although unquantified, it was the observation of increased accumulation of fine sediments from 2007 that prompted this study. Such conditions have been shown to be particularly detrimental to the settlement of coral larvae, which require suitable stable substratum (Babcock and Mundy 1996; Birrell et al. 2005) as well as chemical settlement cues associated with specific benthic bio-films on that substratum (Negri et al. 2001; Webster et al. 2004; Tebben et al. 2011).

Comparing the responses between juvenile and adult communities provides insight into the processes governing coral community composition and dynamics in the study area. For both juvenile and coral cover assemblages, the composition of communities varied between the 2 and $5 \mathrm{~m}$ depths, demonstrating the selective pressure of light availability and exposure to sedimentation. There were, however, few genera that showed consistent preference for the 2 or $5 \mathrm{~m}$ depths; Acropora was the only genus consistently having both higher numbers of juveniles and higher cover at $2 \mathrm{~m}$ compared with $5 \mathrm{~m}$ depth. Acropora was also the only genus to show declines over the study period in both juvenile abundance and cover at both depths. These clear indications of a preference for lower exposure to eutrophication were at odds with the positive relationship of Acropora cover at $5 \mathrm{~m}$ depth with TSS and at both depths with the proportion of fine grainsizes in sediments. The Acropora community on these reefs was dominated by branching species (predominantly $A$. muricata and $A$. micropthalma) that form thickets on sheltered reef crests. These thickets appear to tumble down the reef slope as they grow, which might explain their presence where juvenile densities were low. In contrast to the predominance of branching Acropora species in cover, the majority of juvenile Acropora observed were species that develop corymbose growth forms and from our observations within the turbid waters of the GBR, as a group, suffer high incidence of disease and appear to be transient in the communities studied here.

Interpreting the observed relationships between cover of individual genera and environmental conditions was confounded by the highly variable composition of communities between reefs, the limited number of study reefs and differences in environmental conditions suggesting variable exposure to environmental stressors. The majority of 
genera we identified as varying along environmental gradients could be categorised as having high cover at only one or two reefs compared to low to very low cover elsewhere. A combination of more locations, spread across longer environmental gradients, would improve confidence in assigning distributions of individual genera to environmental parameters.

The changes in the taxonomic composition of communities through time were more informative. Within the juvenile community, 11 genera declined at one or both 2 and $5 \mathrm{~m}$ depths compared to just one genus, Pocillopora, which increased in abundance at $2 \mathrm{~m}$ depths. Pocillopora is particularly susceptible to coral bleaching (Marshall and Baird 2000). Reefs in this region were moderately bleached by high temperatures in 2002, and it is possible that the low initial numbers of juvenile Pocillopora were related to the loss of local broodstock during this event. The consistency of decline among other genera implies a limitation to recruitment. In contrast, with the exception of a decline in Acropora, the composition of cover remained remarkably stable, implying that the majority of colonies present were tolerant of the environmental conditions over the period of high river discharge. This is unsurprising given the large size of many corals, which indicates their tolerance to past fluctuations in environmental conditions.

Our study demonstrates that selective pressures manifest during environmental extremes and vary along depth-gradients and between the life-history stages of corals. Despite this generalisation, exposure to stressful conditions resulting from increased runoff will vary in response to unique combinations of site-specific hydrodynamics, historical disturbance regimes (Harmelin-Vivien 1994), proximity to rivers and the runoff characteristics of those rivers. High rates of sedimentation are generally detrimental to corals (Fabricius 2005, 2011; Erftemeijer et al. 2012). However, these high rates of sedimentation require a combination of supply in the form of high concentrations of suspended particles, measurable as high turbidity, coupled with a low energy hydrodynamic setting that allows these particles to settle and accumulate (Wolanski et al. 2005). While such conditions were typical of the reefs included in this study, even here, shallow water coral communities were less affected by the altered conditions than communities in deeper water. From a regional perspective that recognises individual reefs as supporting small populations of coral taxa belonging to regionally connected meta-populations, it is important that generalisations relating to the effects of runoff be made at the appropriate scale. Studies focused only on reefs in relatively shallow areas exposed to frequent wave energy may overestimate the resilience of communities, while studies in areas predisposed to high rates of sedimentation, such as those at our deeper sites, may underestimate resilience. We suggest that the careful interpretation of community dynamics in the context of detailed environmental data is necessary to tease apart the influence of environmental degradation from naturally varying environmental condition. Further, our data suggest that the primary response to runoff in this region was the result of the short-term (months) exceedance of ambient environmental conditions as a result of pollutants delivered as runoff during high flow conditions. That community selection appeared to occur during extreme conditions, while entirely logical, is a key point demonstrated by our work. The implication is that observations during periods of relatively benign conditions will almost certainly document community dynamics divorced from selective processes.

Acknowledgments We acknowledge the MODIS mission scientists and associated NASA personnel for the production of the data used in this work and Geoscience Australia for the reception of MODIS raw data. The full reprocessing of the MODIS-Aqua time series with the in NASA's SeaDAS software was carried out by the IMOS Satellite Remote Sensing Facility using the National Computing Infrastructure (NCI) high performance distributed storage. The subsequent MODIS processing with the CSIRO algorithms was also carried out at NCI. The shape file used to plot rivers in Fig. 1 was sourced from Geoscience Australia. Monitoring of coral communities included substantial contributions by Paul Costello, Johnston Davidson, Stephan Neale and Damian Thomson. Statistical analysis benefited greatly from the guidance of Murray Logan. We sincerely thank all of the above for their contributions. This project was supported by the Great Barrier Reef Marine Park Authority, through funding from the Australian Government's Caring for our Country Program, the Australian Institute of Marine Science and the CSIRO Wealth from Oceans Flagship. We also thank Jessica Carilli, Curt Storlazzi and one anonymous reviewer for their detailed reviews that substantially improved the manuscript.

Open Access This article is distributed under the terms of the Creative Commons Attribution License which permits any use, distribution, and reproduction in any medium, provided the original author(s) and the source are credited.

\section{References}

Anderson MJ (2001) A new method for non-parametric multivariate analysis of variance. Austral Ecol 26:32-46

Anderson MJ, Willis TJ (2003) Canonical analysis of principle coordinates: a useful method of constrained ordination for ecology. Ecology 84:511-525

Andutta FP, Ridd PV, Wolanski E (2011) Dynamics of hypersaline coastal waters in the Great Barrier Reef. Estuar Coast Shelf Sci 94:299-305

Anthony KRN, Fabricius KE (2000) Shifting roles of heterotrophy and autotrophy in coral energetics under varying turbidity. J Exp Mar Bio Ecol 252:221-253

Anthony KRN, Connolly S (2004) Environmental limits to growth: physiological niche boundaries of corals along turbidity-light gradients. Oecologia 141:373-384

Babcock R, Mundy C (1996) Coral recruitment: consequences of settlement choice for early growth and survivorship in two scleractinian corals. J Exp Mar Bio Ecol 206:179-201 
Bainbridge ZT, Wolanski E, Alvarez-Romero JG, Lewis SE, Brodie JE (2012) Fine sediment and nutrient dynamics related to particle size and floc formation in a Burdekin River flood plume, Australia. Mar Pollut Bull 65:236-248

Birrell CL, McCook LJ, Willis BL (2005) Effects of algal turfs and sediment on coral settlement. Mar Pollut Bull 51:408-414

Brando VE, Dekker AG, Park YJ, Schroeder T (2012) Adaptive semianalytical inversion of ocean color radiometry in optically complex waters. Appl Opt 51:2808-2833

Bray JR, Curtis JT (1957) An ordination of the upland forest communities of southern Wisconsin. Ecol Monogr 27:325-349

Brodie JE, Schroeder T, Rohde K, Faithful J, Masters B, Decker A, Brando V, Maughan M (2010) Dispersal of suspended sediments and nutrients in the Great Barrier Reef lagoon during riverdischarge events: conclusions from satellite remote sensing and concurrent flood-plume sampling. Mar Freshw Res 61:651-664

Brodie JE, Kroon FJ, Schaffelke B, Wolanski EC, Lewis SE, Devlin MJ, Bohnet IC, Bainbridge ZT, Waterhouse J, Davies AM (2012) Terrestrial pollutant runoff to the Great Barrier Reef: An update of issues, priorities and management responses. Mar Pollut Bull 65:81-100

Browne NK, Smithers SG, Perry CT (2010) Geomorphology and community structure of Middle Reef, central Great Barrier Reef, Australia: an inner-shelf turbid zone reef subjected to episodic mortality events. Coral Reefs 29:683-689

Browne NK, Smithers SG, Perry CT (2012) Coral reefs of the turbid inner-shelf of the Great Barrier Reef, Australia: An environmental and geomorphic perspective on their occurrence, composition and growth. Earth-Science Reviews 115:1-20

Bruno JE, Petes LE, Harvell CD, Hettinger A (2003) Nutrient enrichment can increase the severity of coral diseases. Ecol Lett 6:1056-1061

Cooper TF, Uthicke S, Humphrey C, Fabricius KE (2007) Gradients in water column nutrients, sediment parameters, irradiance and coral reef development in the Whitsunday Region, central Great Barrier Reef. Estuar Coast Shelf Sci 74:458-470

Dana JD (1853) On Coral Reefs and Islands. G.P. Putnam and Co., New York, NY

Darling ES, Alvarez-Filip L, Oliver TA, McClanahan TR, Côte IM (2012) Evaluating life-history strategies of reef corals from species traits. Ecol Lett 15:1378-1386

Darwin C (1851) Geological observations on coral reefs, volcanic islands and on South America: Being the geology on the voyage of the Beagle under the command of Captain Fitzroy, R.N., during the years 1832 to 1836 . Smith, Elder and Co., London, UK

De'ath G, Fabricius KE (2010) Water quality as a regional driver of coral biodiversity and macroalgae on the Great Barrier Reef. Ecol Appl 20:840-850

DeVantier LM, De'ath G, Turak E, Done TJ, Fabricius KE (2006) Species richness and community structure of reef-building corals on the nearshore Great Barrier Reef. Coral Reefs 25:329-340

Devlin MJ, Brodie J (2005) Terrestrial discharge into the Great Barrier Reef lagoon: nutrient behaviour in coastal waters. Mar Pollut Bull 51:9-22

Devlin MJ, Schaffelke B (2009) Spatial extent of riverine flood plumes and exposure of marine ecosystems in the Tully coastal region, Great Barrier Reef. Mar Freshw Res 60:1109-1122

Devlin MJ, McKinna LIW, Alvarez-Romero JG, Abott B, Harkness P, Brodie J (2012) Mapping the pollutants in surface waters in the Great Barrier Reef, Australia. Mar Pollut Bull 65:224-235

Devlin MJ, Barry J, Mills DK, Gowen RJ, Foden J, Sivyer D, Tett P (2008) Relationship between suspended particulate material, light attenuation and Secchi depth in UK marine waters. Estuar Coast Shelf Sci 79:429-439
Dikou A, van Woesik R (2006) Survival under chronic stress from sediment load: spatial patterns of hard coral communities in the southern islands of Singapore. Mar Pollut Bull 52:1340-1354

Draut AE, Bothner MH, Field ME, Reynolds RL, Cochran SA, Logan JB, Storlazzi CD, Berg CJ (2009) Supply and dispersal of flood sediment from a steep, tropical watershed: Hanalei Bay, Kaua'i Hawai'i, USA. Geol Soc Am Bull 121:574-585

Erftemeijer PLA, Riegl B, Hoeksema BW, Todd PA (2012) Environmental impacts of dredging and other sediment disturbances on corals: a review. Mar Pollut Bull 64:1737-1765

Fabricius KE (2005) Effects of terrestrial runoff on the ecology of corals and coral reefs: review and synthesis. Mar Pollut Bull 50:125-146

Fabricius KE (2011) Factors determining the resilience of coral reefs to eutrophication: a review and conceptual model. In: Dubinski Z, Stambler N (eds) Coral Reefs: An Ecosystem in Transition. Springer, New York, pp 493-509

Fabricius KE, Wild C, Wolanski E, Abele D (2003) Effects of transparent exopolymer particles and muddy terrigenous sediments on survival of hard coral recruits. Estuar Coast Shelf Sci 57:613-621

Fabricius KE, De'ath G, McCook L, Turak E, Williams D (2005) Changes in algae, coral and fish assemblages along water quality gradients on the inshore Great Barrier Reef. Mar Pollut Bull 51:384-398

Fabricius FE, De'ath GE, Humphrey C, Zagorskis I, Schaffelke B (2013) Intra-annual variation in turbidity in response to terrestrial runoff on near-shore coral reefs on the Great Barrier Reef. Estuar Coast Shelf Sci 116:57-65

Fabricius KE, Cooper TE, Humphrey C, Uthicke S, De'ath G, Davidson J, LeGrand H, Thompson A, Schaffelke B (2012) A bioindicator system for water quality on inshore coral reefs of the Great Barrier Reef. Mar Pollut Bull 65:320-332

Falkowski PG, Jokiel PL, Kinzie RA (1990) Irradiance and corals. In: Dubinski Z (ed) Ecosystems of the world 25: Coral Reefs. Elsevier, New York, pp 98-107

Furnas M, Mitchell A, Skuza M, Brodie JE (2005) In the other 90\%: phytoplankton responses to enhanced nutrient availability in the GBR lagoon. Mar Pollut Bull 51:253-265

Furnas M, Alongi D, McKinnon D, Trott L, Skuza M (2011) Regional-scale nitrogen and phosphorus budgets for the northern $\left(14^{\circ} \mathrm{S}\right)$ and central $\left(17^{\circ} \mathrm{S}\right)$ Great Barrier Reef shelf ecosystem. Cont Shelf Res 31:1967-1990

Golbuu Y, van Woesik R, Richmond RH, Harrison P, Fabricius KE (2011) River discharge reduces reef coral diversity in Palau. Mar Pollut Bull 62:824-831

Haapkyla J, Melbourne-Thomas J, Flavell M, Willis BL (2010) Spatiotemporal patterns of coral disease on Heron Island, Great Barrier Reef, Australia. Coral Reefs 29:1035-1045

Haapkyla J, Melbourne-Thomas J, Flavell M, Willis B (2013) Disease outbreaks, bleaching and a cyclone drive changes in coral assemblages on an inshore reef of the Great Barrier Reef. Coral Reefs 32:815-824

Haapkyla J, Unsworth RKF, Flavell M, Bourne DG, Schaffelke B, Willis BL (2011) Seasonal rainfall and runoff promote coral disease on an inshore reef. PLos One 6:e16893

Harmelin-Vivien ML (1994) The effects of storms and cyclones on coral reefs: a review. J Coast Res 12:211-231

Hennige SJ, Smith DJ, Perkins R, Consalvery M, Paterson DM, Suggett DJ (2008) Photoacclimation, growth and distribution of massive coral species in clear and turbid waters. Mar Ecol Prog Ser 369:77-88

Jones RJ, Bowyer J, Hoegh-Guldberg O, Blackall LL (2004) Dynamics of a temperature-related coral disease outbreak. Mar Ecol Prog Ser 281:63-77 
Jonker M, Johns K and Osborne K (2008) Surveys of benthic reef communities using underwater digital photography and counts of juvenile corals. Long-term monitoring of the Great Barrier Reef. Standard operational procedure 10. Australian Institute of Marine Science. 75 p http://epubs.aims.gov.au/handle/11068/ 8019

Jupiter S, Roff G, Marion G, Henderson M, Schrameyr V, McCulloch M, Hoegh-Guldberg O (2008) Linkages between coral assemblages and coral proxies of terrestrial exposure along a crossshelf gradient on the southern Great Barrier Reef. Coral Reefs 27:887-903

Kennedy K, Schroeder T, Shaw M, Haynes D, Lewis S, Bentley C, Paxman C, Carter S, Brando V, Bartkow M, Hearn L, Mueller J (2012) Long term monitoring of photosystem II herbicides correlation with remotely sensed freshwater extent to monitor changes in the quality of water entering the Great Barrier Reef, Australia. Mar Pollut Bull 65:292-305

Kleypas J, McManus J, Menez L (1999) Environmental limits to coral reef development: where do we draw the line? Am Zool 39:146-159

Kline DI, Kuntz NM, Breitbart M, Knowlton N, Rohwer F (2006) Role of elevated organic carbon levels and microbial activity in coral mortality. Mar Ecol Prog Ser 314:119-125

Kroon FJ, Kuhnert PM, Henderson BL, Wilkinson SN, KinseyHenderson A, Abbott B, Brodie JE, Turner RDR (2012) River loads of suspended solids, nitrogen, phosphorus and herbicides delivered to the Great Barrier Reef lagoon. Mar Pollut Bull $56: 167-181$

Kuhnert PM, Henderson BL, Lewis SE, Bainbridge ZT, Wilkinson SN, Brodie JE (2012) Quantifying total suspended sediment export from the Burdekin River catchment using the loads regression estimator tool. Water Resour Res 48 [doi: 10.1029/ 2011WR011080]

Lambrechts J, Humphery C, McKinna L, Gouge O, Fabricius K, Metha A, Lewis S, Wolanski E (2010) The importance of waveinduced bed fluidisation in the fine sediment budget of Cleveland Bay, Great Barrier Reef. Estuar Coast Shelf Sci 89:154-162

Larcombe P, Costen A, Woolfe KJ (2001) The hydrodynamic and sedimentary setting of nearshore coral reefs, central Great Barrier Reef shelf, Australia: Paluma Shoals, a case study. Sedimentology 48:811-836

Larcombe P, Ridd PV, Prytz A, Willson B (1995) Factors controlling suspended sediment on the inner-shelf coral reefs, Townsville, Australia. Coral Reefs 14:163-171

Legendre P, Legendre L (1998) Numerical ecology, $2^{\text {nd }}$, English. Elsevier, Amsterdam

Lesser MP, Bythell JC, Gates RD, Johnstone RW, Hoegh-Guldberg O (2007) Are infectious diseases really killing corals? Alternative interpretations of the experimental and ecological data. J Exp Mar Bio Ecol 346:36-44

Luick JL, Mason L, Hardy T, Furnas MJ (2007) Circulation in the Great Barrier Reef Lagoon using numerical tracers and in situ data. Cont Shelf Res 27:757-787

Loya Y (1976) Effects of water turbidity and sedimentation on community structure of Puerto Rican corals. Bull Mar Sci 26:450-466

Loya Y (2004) The coral reefs of Eilat-past, present and future: Three decades of coral community structure studies. In: Rosenberg E, Loya Y (eds) Coral health and disease. Springer, Berlin Heidelberg, New York, pp.1-34

Marshall PA, Baird AH (2000) Bleaching of corals on the Great Barrier Reef: differential susceptibilities among taxa. Coral Reefs 19:155-163

McCulloch MT, Fallon S, Wyndham T, Hendy E, Lough J, Barnes D (2003) Coral record of increased sediment flux to the inner Great Barrier Reef since European settlement. Nature 421:727-730
Miller IR (2003) Crown-of-thorns starfish and coral surveys using the manta tow and scuba search techniques. Standard operational procedure No.8. SOP 8. Australian Institute of Marine Science. p. 43, http://epubs.aims.gov.au/handle/11068/7487

Negri AP, Webster NS, Hill RT, Heyward AJ (2001) Metamorphosis of broadcast spawning corals in response to bacteria isolated from crustose algae. Mar Ecol Prog Ser 23:121-131

Oksanen J, Guillaume Blanchet F, Kindt R, Legendre P, Minchin PR, O'Hara RB, Simpson GL, Solymos P, Stevens MHH, Wagner H (2013) vegan: community ecology package. $\mathrm{R}$ package version 2.0-8. http://CRAN.R-project.org/package=vegan

Orpin AR, Ridd PV (2012) Exposure of inshore corals to suspended sediments due to wave-resuspension and river plumes in the central Great Barrier Reef: a reappraisal. Cont Shelf Sci 47:55-67

Pastorok RA, Bilyard GR (1985) Effects of sewage pollution on coral-reef communities. Mar Ecol Prog Ser 21:175-189

Perry CT, Smithers SG, Johnson KE (2009) Long-term coral community records from Lugger Shoal on the terrigenous inner-shelf of the Great Barrier Reef, Australia. Coral Reefs 28:941-948

Perry CT, Smithers SG, Palmer SE, Larcombe P, Johnson KE (2008) A 1200 year paleoecological record of coral community development from the terrigenous inner-shelf of the Great Barrier Reef. Geology 36:691-694

Pinheiro J, Bates D, DebRoy S, Sarkar D, R Core Team (2013) nlme: linear and nonlinear mixed effects models. $\mathrm{R}$ package version 3.1-109

Qin Y, Brando VE, Dekker AG, Blondeau-Patissier D (2007) Validity of SeaDAS water constituents retrieval algorithms in Australian tropical coastal waters. Geophys Res Lett 34:L21603

Roff G, Clark TR, Reymond CE, Zhao J, Feng Y, McCook LJ, Done TJ, Pandolfi JM (2013) Palaeoecological evidence of a historical collapse of corals at Pelorus Island, inshore Great Barrier Reef, following European settlement. Proc R Soc Lond B Biol Sci 280:20122100

Rogers CS (1979) The effect of shading on coral reef structure and function. J Exp Mar Bio Ecol 41:269-288

Rogers CS (1983) Sublethal and lethal effects of sediments applied to common Caribbean reef corals in the field. Mar Pollut Bull 14:378-382

Schroeder T, Behnert I, Schaale M, Fischer J, Doerffer R (2007) Atmospheric correction algorithm for MERIS above case-2 waters. Int J Remote Sens 28:1469-1486

Schroeder T, Devlin MJ, Brando VE, Decker AG, Brodie JE, Clementson LA, McKinna L (2012) Inter-annual variability of wet season freshwater plume extent into the Great Barrier Reef lagoon based on satellite coastal ocean colour observations. Mar Pollut Bull 65:210-223

Sheppard CRC (1982) Coral populations on reef slopes and their major controls. Mar Ecol Prog Ser 7:83-115

Stafford-Smith MG (1993) Sediment-rejection efficiency of 22 species of Australian Scleractinian corals. Mar Biol 115:229-243

Storlazzi CD, Field ME, Bothner MH, Presto MK (2009) Sedimentation processes in a coral reef embayment: Hanalei Bay, Kauai. Mar Geol 264(3):140-151

Storlazzi CD, Ogston AS, Bothner MH, Field ME, Presto MK (2004) Wave- and tidally-driven flow and sediment flux across a fringing coral reef: Southern Molokai, Hawaii. Cont Shelf Res 24:1397-1419

Sutherland KP, Porter JW, Torres C (2004) Disease and immunity in Caribbean and Indo-Pacific zooxanthellate corals. Mar Ecol Prog Ser 266:273-302

Tebben J, Tapiolas DM, Motti CA, Abrego D, Negri AP, Blackall L, Steinberg PD, Harder T (2011) Induction of larval 
metamorphosis of the coral Acropora millepora by tetrabromopyrrole isolated from a Pseudoalteromonas bacterium. PLoS One 6:e19082

Titlyanov EA, Latypov YY (1991) Light-dependence in scleractinian distribution in the sublittoral zone of the South China Sea Islands. Coral Reefs 10:133-138

Todd PA (2008) Morphological plasticity in Scleractinian corals. Biol Rev 83:315-337

Tomascik T, Sanders F (1987) Effects of eutrophication an reefbuilding corals. II. Structure of scleractinian coral communities on fringing reefs, Barbados, West Indies. Mar Biol 94:53-75

Uthicke S, Thompson A, Schaffelke B (2010) Effectiveness of benthic foraminifera and coral assemblages as water quality indicators on inshore reefs of the Great Barrier Reef, Australia. Coral Reefs 29:209-225

Van Duin EHS, Blom G, Johannes Los F, Maffione R, Zimmerman R, Cerco CF, Dortch M, Best EPH (2001) Modelling underwater light climate in relation to sedimentation, resuspension, water quality and autotrophic growth. Hydrobiologia 444:25-42

van Woesik R, Tomascik T, Blake S (1999) Coral assemblages and physico-chemical characteristics of the Whitsunday Islands: evidence of recent community changes. Mar Freshw Res 50:427-440

Vega Thurber RL, Burkepile DE, Fuchs C, Shantz AA, McMinds R, Zaneveld JR (2014) Chronic nutrient enrichment increases prevalence and severity of coral disease and bleaching. Glob Chang Biol 20:544-554
Walker DI, Ormond RFG (1982) Coral death from sewage and phosphate pollution at Aqaba, Rea Sea. Mar Pollut Bull 13:21-25

Weber M, Lott C, Fabricius KE (2006) Sedimentation stress in a scleractinian coral exposed to terrestrial and marine sediments with contrasting physical, organic and geochemical properties. J Exp Mar Bio Ecol 336:18-32

Weber M, de Beer D, Lott C, Polerecky L, Kohis K, Abed RMM, Ferdelman TG, Fabricius KE (2012) Mechanisms of damage to corals exposed to sedimentation. Proc Natl Acad Sci U S A 109:E1558-E1567

Webster NS, Smith LD, Heyward AJ, Watts JEM, Webb RI, Blackall LL, Negri AP (2004) Metamorphosis of a scleractinian coral in response to microbial biofilms. Appl Environ Microbiol 70:1213-1221

Wolanski E, Fabricius FE, Spagnol S, Brinkman R (2005) Fine sediment budget on an inner-shelf coral-fringed island, Great Barrier Reef of Australia. Estuar Coast Shelf S 65:153-158

Wolanski E, Fabricius K, Cooper T, Humphrey C (2008) Wet season fine sediment dynamics on the inner shelf of the Great Barrier Reef. Estuar Coast Shelf Sci 77:755-762

Wood SN (2006) Generalized additive models: an introduction with R. Chapman and Hall/CRC Press, Boca Raton, FL

Wooldridge S, Brodie J, Furnas M (2006) Exposure of inner-shelf reefs to nutrient enriched runoff entering the Great Barrier Reef Lagoon: Post-European changes and the design of water quality targets. Mar Pollut Bull 52:1467-1479 